Volume 4 • Nomor 1 • Oktober 2020

Pege (Hal.) : $79-92$

(C) Universitas Pamulang

JL.Surya Kencana No.1 Pamulang, Tangerang Selatan - Banten

Telp. (021) 7412566, Fax (021) 7412491

website. : Email : jurnalmarketing.unpam@gmail.com

\title{
Loyalitas Merek Pada Produk Mie Samyang di Jakarta
}

\author{
Firstianty Wahyuhening Fibriany ${ }^{1}$; Yumi Novita Dewi ${ }^{2}$ \\ ${ }^{1}$ Universitas Bina Sarana Informatika, ririenfirst@gmail.com \\ ${ }^{2}$ Sekolah Tinggi Manajamen Informatika dan Komputer Nusa Mandiri, yumi.ymd@nusamandiri.ac.id
}

\begin{abstract}
Abstrak. Mie Samyang adalah merek mie instan kekinian yang berasal dari korea dan digemari oleh masyarakat. Penelitian ini dilakukan dengan tujuan mengetahui loyalitas merek pada produk mie korea samyang yang dilakukan oleh konsumen saat berlakukannya Pembatasan Sosial Berskala Besar (PSBB) yang diakibatkan oleh virus Covid 19 yang terjadi di Jakarta. Pembelian dan pembelanjaan konsumen pada saat diberlakukannya PSBB, akan sangat berpengaruh terhadap loyalitas konsumen pada suatu merek produk. Peneliti melakukan penelitian dengan menggunakan metode deskriptif dengan pendekatan kuantitatif dengan teknik pengumpulan data yang digunakan oleh peneliti adalah menggunakan instrumen pertanyaan yang terstruktur dengan menggunakan google form, yang kemudian dioleh dengan menggunakan SPSS. Peneliti menggunakan sampel sebanyak 80 responden dengan kriteria pernah mengkonsumsi mie Samyang dengan batasan umur 12 hingga 30 tahun. Untuk menunjang penelitian ini, peneliti menggunakan teknik Convenience Sampling dalam pengambilan data penelitian. Sedangkan untuk menganalisis datanya dilakukan adalah dengan melakukan deskriptif kuantitatif pada variabel tingkatan loyalitas pelanggan yang suka berpindah,kebiasaan konsumen dalam melakukan pembelian, Kepuasan pembeli agar tidak beralih, Kesukaan terhadap Merek, dan Komitmen pelanggan terhadap merek produk dengan menggunakan skala likert. Hasil penelitian ini secara parsial menunjukkan bahwa pelanggan kurang loyal terhadap pembelian mie Samyang, pelanggan sering berpindah produk dan pembeli yang memiliki komitmen untuk melakukan pembelian pun rendah.
\end{abstract}

\section{Kata Kunci: Ekuitas Merek; Minat Beli; Loyalitas Merek}

\begin{abstract}
Mie Samyang is a contemporary instant noodle brand originating from Korea and is favored by the public. This research was conducted with the aim of knowing the brand loyalty of the Korean samyang noodle products carried out by consumers during the implementation of LargeScale Social Restrictions (PSBB) caused by the Covid 19 virus that occurred in Jakarta. Consumer purchases and spending at the time the PSBB is implemented will greatly affect consumer loyalty to a product brand. Researchers conducted research using descriptive methods with a quantitative approach with data collection techniques used by researchers was to use a structured question instrument using google form, which was then obtained using SPSS. Researchers used a sample of 80 respondents with the criteria of having consumed Samyang noodles with an age limit of 12 to 30 years. To support this research, researchers used the convenience sampling technique in collecting research data. Meanwhile, to analyze the data, it is done by doing a quantitative descriptive of the variable level of customer loyalty who likes to move, consumer habits in making purchases, buyer satisfaction so as not to switch, liking to brands, and customer commitment to product brands using a Likert scale. The results of this study partially show that customers are less loyal to the purchase of Samyang noodles, customers often switch products and buyers who have a commitment to make purchases are low.
\end{abstract}

Keywords: Brand Equity; Purchase Interests; Brand Loyalty 


\section{A. PENDAHULUAN}

Gaya hidup masyarakat saat ini banyak berubah, terutama dalam hal konsumsi makanan. Beragam produk makanan asing yang ada saat ini dari berbagai Negara, baik di minimarket, supermarket, maupun di pasar modern lainnya telah menjadi hal yang umum bagi masyarakat. Masyarakat pun saat ini sangat senang dengan makanan instan dan makanan yang sedang tranding. Hal yang serupa dengan mie instan.

Negara kita termasuk dalam negara dengan penduduk Islam terbesar di dunia. Menjaga nilai halal produk yang dikonsumsinya, merupakan hal utama yang harus menjadi prioritas. Saat ini, banyak sekali produk mie instan impor yang masuk ke Indonesia, salah satunya adalah mie asal korea yaitu, Samyang. Produk mie korea ini adalah merek mie instan yang sangat popular di Indonesia terutama dikalangan milenial. Meskipun terdapat produknya yang tidak halal, namun di Indonesia dijual produk dari Samyang telah memiliki sertifikat halal, yaitu mie dengan varian Ramen Ayam Pedas dan Ramen Keju Pedas . Dua varian mie ini diimpor khusus oleh PT Korinmus.

Untuk menghadapi persaingan merek yang ada saat ini, terutama pada produk mie instan, mie Samyang dengan dua varian halal yang sedang hits ini harus dapat menciptakan produk yang memiliki identitas tersendiri, memiliki nilai kegunaan produk dan memiliki kualitas produk yang mampu membuat pelanggan terpuaskan dan menyukai produk ini. Dengan konsumen terpuaskan, maka ini akan menjadikan kekuatan bagi perusahaan dalam memenangkan persaingan yang ada dan untuk menciptakan loyalitas konsumennya.

Loyalitas konsumen pada suatu merek produk tertentu yang dikeluarkan oleh sebuah perusahaan, merupakan salah satu tujuan akhir dari pencapaian kesuksesan suatu merek dimana perusahan dapat menjadikan merek tersebut selalu diingat dibenak konsumen dan dapat mengahasilkan pembelian produk secara berulang-ullang (repetition), sehingga konsumen tidak beralih melakukan pembeliannya kepada merek yang lain (Alma, 2018). Loyalitas yang dilakukan oleh pelanggan dalam melakukan pembelian barang, terutama pembelian yang berulang adalah hal yang sangat penting, terutama pada kondisi dimana tingkat persaingan penjualan yang sangat ketat dan pertumbuhan pembelian yang dilakukan oleh pembeli cukup rendah.

Kondisi dimana perusahaan harus bersaing dengan yang lain, loyalitas pelanggan pada merek tertentu sangat dibutuhkan. Hal ini dimaksudkan agar perusahaan dapat terus bertahan. Perusahaan harus terus berupaya untuk mempertahankan loyalitas merek dari pelanggan dengan melakukan berbagai upaya strategis.

Pembeli sulit untuk dipuaskan. Namun, perusahaan harus mampu untuk menjaga reputasi, menjaga kulitasnya dan tetap berusaha dalam memenuhi apa yang konsumen butuhkan agar mereka tetap membeli produk perusahaan tersebut. Menurut Setiawan dalam (Widadi \& Wadji, 2015) dalam beberapa penelitian yang berkaitan dengan loyalitas menunjukkan bahwa, untuk menarik satu pelanggan baru, biaya yang dikeluarkan oleh perusahaan akan lebih mahal dibandingkan dengan ongkos yang dikeluarkan untuk mempertahankan pelanggan lama. Demikian hal nya dengan mie Samyang. Pelanggan Mie ini sudah sangat banyak. Namun, banyak juga pesaing yang mengeluarkan produk yang sama dengan mie Samyang. 
Pada penelitian sebelumnya yang dilakukan oleh (Susanto, Ferdinand, Gunawan, \& Sihombing, 2018), meneliti mengenai loyalitas merek khususnya pada jasa penerbangan dan diperoleh hasil bahwa nilai yang dirasakan oleh penumpang atau pelanggan tidak ada dampak terhadap loyalitas merek, namun untuk mengetahui siapa pelanggan kita, kepercayaan seseorang terhadap suatu merek, dan kualitas layanan merupakan hal yang menghasilkan dampak bagi loyalitas pelanggan terhadap merek.

Dalam hal lainnya, penelitian terhadap loyalitas merek dilakukan oleh (Nabilla, 2017). Hasil penelitian tersebut mengatakan bahwa terdapat dampak langsung citra sebuah merek terhadap minat beli konsumen, yaitu menghasilkan nilai yang positif dan signifikan. Pada hal yang menyangkut pengaruh yang langsung diterima pada citra merek terhadap loyalitas merek juga menghasilkan nilai positif, namun tidak menghasilkan hasil yang signifikan. Dalam hal pengaruh langsung minat beli terhadap loyalitas merek bernilai positif dan signifikan dan pengaruh tidak langsung citra merek terhadap loyalitas merek dipengaruhi oleh minat beli.

Berdasarkan pemaparan latar belakang, penelitian sebelum yang dilakukaan oleh peneliti lain dan latar belakang ketertarikan peneliti terhadap apa yang telah diuraikan, maka penulis tertarik untuk menganalisis dan melihat loyalitas konsumen terhadap merek mie Samyang, yaitu dengan menganalisis konsumen yang melakukan perpindahan pembelian, menganalisis kebiasaan pembelian, menganalisis kepuasan pembeli, menganalisis kesukaan terhadap merek, dan menganalisis komitmen pembeli.

\section{B. KAJIAN LITERATUR}

\section{Merek}

Merek berarti nama atau simbol yang dibuat oleh perusahaan ataupun organisasi dan ditujukan untuk memberikan identitas ataupun ciri yang membedakan satu produk dengan yang lainnya. Selain itu, nama tersebut dapat juga dijadikan ciri untuk membedakan satu merek dengan merek lainnya sebagai pesaing (Alma, 2018).

Merek pada produk atau jasa sangat penting peranannya. Salah satu peranan suatu merek adalah untuk menjadi jembatan antara harapan konsumen dengan kenyataan. Pesaing mungkin saja menawarkan produk yang mirip dan hampir sama, namun tidak semua peruahaan menawarkan janji emosional yang sama kepada pelanggan (Tjiptono, 2015).

\section{Kepuasan Pelanggan}

Diambil dari (Kotler \& Keller, 2018) kepuasan pelanggan adalah perasaan seseorang yang timbul, apakah berupa perasanaan senang atau kecewa yang dirasakan oleh seoarng pelanggan atau konsumen. Perasaan ini timbul setelah mereka membandingkan antara kinerja yang ada pada produk yang ditangkap oleh pelanggan terhadap kinerja produk yang diharapkan pelanggan. Apabila kinerja merek produk berada tidak sesuai dengan harapan, maka mereka merasa tidak terpuaskan. Sebaliknya, jika sesuai dengan harapan yang mereka inginkan bahkan bisa lebih dari harapan yang mereka bayangkan, maka pelanggan merasa puas atau amat senang dan dapat mengabarkan kepada yang lain.

Salah satu faktor yang menjadi penentu dari kepuasan pelanggan adalah persepsi mereka terhadap kualitas produk dan jasa yang dihasilkan oleh suatu hal (Nabilla, 2017). Sehingga, persepsi mereka terhadap produk atau jasa yang diberikan akan memiliki pengaruh pada tingkat kepentingan pelanggan, kepuasan pelanggan, nilai dalam melakukan pembelian, dan kesetiaan mereka dalam melakukan pembelian selanjutnya.

\section{Loyalitas Merek}

Loyalitas digunakan oleh perusahaan untuk menggambarkan kesediaan pelanggan perusahaan agar terus melakukan pembelian dalam jangka yang panjang, yaitu dengan 
melakukan pembelian dan menggunakan barang dan jasanya secara berulang dan enggan untuk menggunakan produk yang lain. Bahkan, mereka melakukan hal yang lebih baik lagi yaitu secara eksklusif dan dengan suka rela merekomendasikan produk yang dikeluarkan oleh perusahaan tersebut kepada orang lain.

Menurut Rizan, Saidani, \& Sari (2012) dalam (Nabilla, 2017) dikatakan bahwa loyalitas merek adalah suatu keadaan, dimana para pelanggan suatu perusahaan melakukan sikap yang positif terhadap sebuah merek yang dikeluarkan oleh perusahaan tersebut. Pelanggan yang setia akan memiliki komitmen pada sebuah merek dan cenderung untuk melakukan pembelian ulang dimasa yang akan datang.

Penelitian yang dilakukan oleh (Samsudin, 2019) Loyalitas merek ini memiliki hubungan emosional pelanggan yang erat dengan perusahaan. Hal ini terlihat dengan munculnya transformasi perilaku pembelian barang secara berulang yang dilakukan oleh pelanggan terhadap produk yang ditawarkan. Dalam rangka meningkatkan loyalitas konsumen, salah satu cara yang dapat dilakukan adalah dengan memberikan pelayanan, baik pada produk maupun jasa dengan kualitas yang terbaik, yang diharapkan dapat membuat pelanggan kembali untuk melakukan transaksi pembelian.

\section{Ekuitas Merek}

Pada merek yang dikeluarkan oleh suatu perusahaan, terdapat nilai yang terdapat pada produk yang dikenal dengan ekuitas merek. Menurut Aaker (1997) dalam (Putri, Kusumaningrum, \& Arijanto, 2014) ekuitas merek adalah liabilitas merek dan seperangkat asset suatu produk yang dikaitkan pada suatu merek, nama, simbol tertentu, yang mampu memberikan nilai tambah pada sebuah produk atau jasa, baik pada perusahaan maupun pada pelanggannya. Ditambahkan oleh (Putri et al., 2014) ekuitas merek dapat dikelompokan menjadi lima kategori, yaitu Kesadaran terhadap Merek, Asosiasi sebuah Merek, Persepsi konsumen terhadap kualitas barang atau jasa, loyalitas pada merek, dan aset-aset merek yang lain.

Kesadaran Merek

Kesadaran pembeli terhadap merek dalam ekuitas merek, merupakan kemampuan seorang calon pembeli dalam hal untuk mengenali, mengetahui, memahami dan mengingat kembali bahwa suatu merek produk merupakan bagian dari kategori produk tertentu.

\section{Asosiasi Merek}

Asosiasi merek merupakan segala hal yang dikaitkan pada ingatan pelanggan mengenai merek suatu produk. Asosiasi dalam ekuitas merek ini merupakan bagian yang ada di dalam merek tersebut. Pada asosiasi merek ini memiliki suatu tingkat kekuatan daya tarik konsumen untuk melakukan pembelian. Antara satu merek dengan merek lain akan menimbulkan keterkaitan yang lebih tinggi, apabila pelanggan mempunyai banyak pengalaman yang berhubungan dengan merek produk yang pernah dibelinya tersebut.

\section{Persepsi Kualitas}

Pada sebuah merek terdapat pandangan konsumen terhadap keseluruhan kualitas barang dan jasa atau keunggulan yang sama dengan yang diharapkan oleh konsumen. Dimensi kualitas jasa pada suatu produk dibagi menjadi lima dimensi pokok yaitu kehandalan produk, daya tangkap produk terhadap kebutuhan pelanggan, jaminan yang diberikan, empati perusahaan terhadap pelanggan, dan bukti fisik dari poduk tersebut.

\section{Loyalitas Merek}

Loyalitas merek merupakan dimensi pokok dari ekuitas merek itu sendiri. Pelanggan yang loyal terhadap suatu merek, akan menjadi hambatan masuk bagi pesaing. Pesaing akan sulit untuk mengambil pasar dari konsumen yang telah loyal pada 
suatu merek. Dalam hal ditetapkannya harga yang sesuai, ketersediaan waktu yang dimiliki oleh perusahaan untuk melakukan inovasi produk dan pelayanan yang berbeda yang tidak dilakukan oleh pesaing, dapat menjadi pelindung dari kemungkinan kompetisi harga bagi perusahaan. Pada Gambar 1 digambarkan piramida ukuran kesetiaan konsumen terhadap suatu merek.

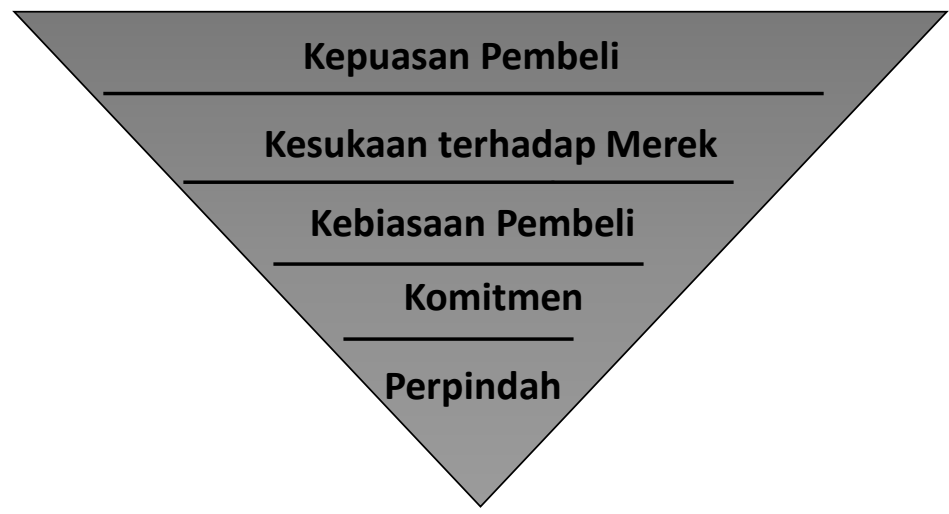

Gambar 1. Piramida Loyalitas Merek

\title{
C. METODOLOGI PENELITIAN
}

\begin{abstract}
Jenis Penelitian
Penelitian menggunakan pendekatan deskriptif kuantitatif. Penelitian deskriptif pada penelitian ini merupakan penelitian yang dilaksanakan peneliti untuk mendapatkan nilai variabel mandiri, baik satu variabel atau lebih, yaitu variabel bebas tanpa membuat dan melakukan perbandingan atau menghubungkannya dengan variabel lainnya (Widoyoko, 2017). Sedangkan pada penelitian kuantitatif yang dilakukan pada penelitian ini adalah menekankan penelitiannya dengan melakukan analisis pada data berupa angka yang diperoleh dengan menggunakan metode statistik, sehingga diperoleh signifikansi hubungan antar variabel yang diteliti (Widoyoko, 2017).
\end{abstract}

\section{Jenis Data}

Untuk data pada penelitian ini, peneliti menggunakan jenis data primer kuantitatif, yang bersumber dari pengisian kuisioner berupa pertanyaan dengan skala likert. Desain penelitian yang dilakukan oleh peneliti pada loyalitas merek ini dilaksanakan menggunakan metode survei dengan menyebarkan angket berupa kuesioner yang disebarkan dengan menggunakan aplikasi google form kepada responden.

\section{Teknik Pengambilan Sampel}

Peneliti melakukan pengambilan sampel dengan menggunakan teknik yang sama dengaan yang digunakan oleh (Nursaman, Sumarwan, \& Djohar, 2014), yaitu metode convenience sampling. Maksudnya adalah sampel yang diperoleh bertujuan untuk kemudahan bagi peneliti dalam mendapatkan sampel. Populasi penelitian ini adalah konsumen yang berada di Jakarta yang pernah mengkonsumsi mie Samyang. Jumlah sampel yang diambil adalah sebanyak 80 reponden. Penentuan responden ini diambil dari (Hartanto, 2020) bahwa ukuran sampel minimal adalah 30. Responden yang ada di Jakarta mengisi kuesioner penelitian dengan menggunakan batasan rentang usia 12-30 tahun dan pernah mengkonsumsi mie Samyang. 


\section{Teknik Analisis Data}

Proses dilakukan dengan penyederhanaan berupa rangkuman data ke dalam bentuk yang lebih mudah dibaca, kemudian diinterprestasikan setelah data dianalisis dengan menggunakan excel dan SPSS merupakan teknik analisis data yang digunakan pada penelitian kali ini. Data yang diperoleh dari pengisian kuisioner di analisa dengan mendeskripsikan atau menggambarkan 80 data responden. Data tersebut kemudian disajikan dalam bentuk angka maupun penjabaran yang menjelaskan hasil temuan tersebut. Variabel yang dipakai untuk data pada penelitian ini adalah variabel mengenai tingkatan loyalitas pelanggan yang suka berpindah, pembeli yang memiliki kebiasaan dalam pembelian, pembeli yang puas dengan biaya peralihan, pembeli yang menyukai merek, dan pembeli yang memiliki komitmen terhadap merek suatu produk. Selanjutnya variabel diolah dengan menggunakan skala likert menentukan skor atas setiap pertanyaan dalam kuesioner yang disebarkan. Setelah itu, peneliti melakukan perhitungan pada lima dimensi tingkat loyalitas konsumen yaitu Konsumen yang pindah, Kebiasaan Pembeli, Kepuasan Pembeli, Menyukai Merek, dan Komitmen Pembeli.

\section{HASIL DAN PEMBAHASAN}

\section{Deskripsi Responden}

Hasil dari pengolahan data yang diperoleh, peneliti diperoleh hasil untuk jenis kelamin dan usia responden sebagai berikut:

Tabel 1. Jenis Kelamin

\begin{tabular}{lll}
\hline Jenis Kelamin & Frekuensi & Persentase (\%) \\
\hline Laki-Laki & 36 & 45 \\
Perempuan & 44 & 55 \\
\hline Jumlah responden & 80 & 100 \\
\hline
\end{tabular}

Sumber: Data primer yang diolah, 2020

Tabel 2. Usia

\begin{tabular}{lcc}
\hline Usia (Tahun) & Frekuensi & Persentase (\%) \\
\hline $12-17$ & 4 & 5 \\
$17-21$ & 54 & 67.5 \\
$22-26$ & 16 & 20 \\
$26-30$ & 6 & 7.5 \\
\hline Jumlah responden & 80 & 100 \\
\hline
\end{tabular}

Sumber: Data primer yang diolah, 2020

Berdasarkan hasil tabel 1 dan tabel 2. di atas, terlihat bahwa konsumen perempuan lebih banyak, artinya bahwa yang mengenal dan pernah mengkonsumsi mie Samyang adalah perempuan dan usia responden yang pernah mengkonsumsi mie Samyang adalah usia 17 hingga 21 tahun. Dengan data seperti di atas, maka perusahaan sebaiknya melihat 
potensi pasar yang banyak tersebut untuk selalu di kelola dengan baik, agar konsumen tetap loyal terhadap merek yang di keluarkan.

\section{Uji Validitas dan Reliabilitas Data Loyalitas Pelanggan}

Uji Validitas

Uji ini merupakan uji untuk melihat apakah varibel yang digunakan untuk penelitian ini valid atau tidak. Uji validitas ini digunakan untuk menentukan nilai Corrected Item-Total Correlation terhadap nilai pada tabel $r$ Product Moment. Berdasarkan hasil uji validitas seperti yang pada lampiran 1, terlihat bahwa nilai $r$ hitung $>0,312$ sehingga dengan hasil tersebut, menunjukkan bahwa butir-butir pertanyaan seluruhnya bisa digunakan.

Tabel 3. Hasil Uji Validitas

\begin{tabular}{|c|c|c|c|}
\hline Variabel & r hitung & $r$ tabel & Keterangan \\
\hline $\begin{array}{l}\text { Membeli Mie lain dengan jenis yang } \\
\text { mirip dengan Samyang }\end{array}$ & 0.580 & 0,312 & Valid \\
\hline $\begin{array}{l}\text { Membeli mie tergantung dari harga } \\
\text { yang ditawarkan }\end{array}$ & 0.706 & 0,312 & Valid \\
\hline $\begin{array}{l}\text { Harga sesuai dengan produk yang } \\
\text { ditawarkan }\end{array}$ & 0.657 & 0,312 & Valid \\
\hline $\begin{array}{l}\text { Kualitas mie Samyang baik sesuai } \\
\text { dengan harapan }\end{array}$ & 0.655 & 0,312 & Valid \\
\hline $\begin{array}{l}\text { Merekomendasikan mie Samyang } \\
\text { kepada orang lain }\end{array}$ & 0.626 & 0,312 & Valid \\
\hline Melakukan pembelian bila ada promo & 0.642 & 0,312 & Valid \\
\hline Rasa ayam dari produk ini mendominasi & 0.718 & 0,312 & Valid \\
\hline Menyukai varian yang di tawarkan & 0.722 & 0,312 & Valid \\
\hline $\begin{array}{l}\text { Kemasan yang menjaga produk tetap } \\
\text { baik layak di konsumsi }\end{array}$ & 0.492 & 0,312 & Valid \\
\hline $\begin{array}{l}\text { Produk ini sesuai dengan berat isi } \\
\text { didalamnya }\end{array}$ & 0.419 & 0,312 & Valid \\
\hline $\begin{array}{l}\text { Tetap melakukan pembelian walaupun } \\
\text { ada produk yang mirip dengan mie } \\
\text { Samyang }\end{array}$ & 0.561 & 0,312 & Valid \\
\hline $\begin{array}{l}\text { Melakkan pembelian mie Samyang } \\
\text { secara rutin tiap bulan }\end{array}$ & 0.465 & 0,312 & Valid \\
\hline
\end{tabular}

Sumber: Data Primer, Diolah

\section{Uji Reliabilitas}

Hasil yang diperoleh dari uji reliabilitas adalah terdapat pada Tabel 5 . Nilai terhadap Cronbach's Alpha mendapatkan nilai lebih besar dari nilai $r$, yaitu 0,6, sehingga variabel yang diujikan dikatakan reliable.

Adapun dasar dalam pengambilan keputusan dalam uji reliabilitas yaitu :

Jika nilai Crornbach's Alpha > 0.60 maka kuesioner/angket dapat dikatakan reliabel atau konsisten Sementara jika cronbach's Alpha < 0,60 maka kuesioner dinyatakan tidak reliabel 
Tabel 4. Cronbach Variabel

\section{Reliability Statistics}

Cronbach's Cronbach's Alpha Based on

Alpha $\quad$ Standardized Items $\quad$ N of Items

Sumber: Pengolahan data SPSS, 2020

Tabel 5. Uji Reabilitas

\begin{tabular}{|c|c|c|}
\hline Variabel & $\begin{array}{l}\text { Cronbach's } \\
\text { Alpha if Item }\end{array}$ & Keterangan \\
\hline $\begin{array}{l}\text { Membeli Mie lain dengan jenis yang mirip } \\
\text { dengan Samyang }\end{array}$ & 0,833 & Reliabel \\
\hline $\begin{array}{l}\text { Membeli mie tergantung dari harga yang } \\
\text { ditawarkan }\end{array}$ & 0,823 & Reliabel \\
\hline $\begin{array}{l}\text { Harga sesuai dengan produk yang } \\
\text { ditawarkan }\end{array}$ & 0,828 & Reliabel \\
\hline $\begin{array}{l}\text { Kualitas mie Samyang baik sesuai dengan } \\
\text { harapan }\end{array}$ & 0,827 & Reliabel \\
\hline $\begin{array}{l}\text { Merekomendasikan mie Samyang kepada } \\
\text { orang lain }\end{array}$ & 0,834 & Reliabel \\
\hline Melakukan pembelian bila ada promo & 0,828 & Reliabel \\
\hline Rasa ayam dari produk ini mendominasi & 0,821 & Reliabel \\
\hline Menyukai varian yang di tawarkan & 0,822 & Reliabel \\
\hline $\begin{array}{l}\text { Kemasan yang menjaga produk tetap baik } \\
\text { layak di konsumsi }\end{array}$ & 0,839 & Reliabel \\
\hline $\begin{array}{l}\text { Produk ini sesuai dengan berat isi } \\
\text { didalamnya }\end{array}$ & 0,843 & Reliabel \\
\hline $\begin{array}{l}\text { Tetap melakukan pembelian walaupun } \\
\text { ada produk yang mirip dengan mie } \\
\text { Samyang }\end{array}$ & 0,835 & Reliabel \\
\hline $\begin{array}{l}\text { Melakukan pembelian mie Samyang } \\
\text { secara rutin tiap bulan }\end{array}$ & 0,840 & Reliabel \\
\hline
\end{tabular}

Data : Pengolahan dengan SPSS, 2020 


\section{Analisa Perpindahan Pelanggan}

Analisa yang dilakukan ini merupakan analisa yang dilakukan terhadap Pembeli atau Konsumen yang sensitif terhadap merek mie lain yang mirip dengan mie Samyang dan harga yang ditawarkan, maka mereka yang menjawab "sering" dan "selalu". Berikut ini adalah Tabel yang menyajikan hasil perhitungan Switcher merek Mie Samyang.

Tabel 6 Perhitungan Analisa Switcher (Perpindahan)

\begin{tabular}{lllllll}
\hline Jawaban & $\mathbf{f}$ & $\mathbf{X}$ & $\mathbf{f . X}$ & $\mathbf{X}^{2}$ & $\mathbf{f . X ^ { 2 }}$ & $\%$ \\
\hline Tidak pernah pindah & 6 & 1 & 6 & 1 & 6 & 7.5 \\
\hline Jarang pindah & 42 & 2 & 84 & 4 & 168 & 52.5 \\
\hline Sering pindah & 20 & 3 & 60 & 9 & 180 & 25 \\
\hline Selalu pindah & 12 & 4 & 48 & 16 & 192 & 15 \\
\hline Total & 80 & & 198 & & 546 & 100 \\
\hline
\end{tabular}

Sumber: Pengolahan Data Primer, 2020

$$
\text { Rata-rata } \quad=\frac{\sum f . X}{\sum f \text { Total }}=\frac{198}{80}=2,47
$$$$
\text { Switcher } \quad=\frac{32}{80} \times 100=40 \%
$$

Hasil dari tabel 6 disebutkan, bahwa rata-rata mereka yang sensitif yang dapat berpindah ke produk lain terhadap perubahan harga berjumlah 32 orang atau sebesar $40 \%$. Selain informasi tersebut, hasil interpretasi kelompok responden dengan menggunakan rentang skala:

$$
\begin{aligned}
& 1,00-1,75=\text { Sangat Jelek } \\
& 1,75-2,50=\text { Jelek } \\
& 2,50-3,25=\text { Baik } \\
& 3,25-4,00=\text { Sangat Baik }
\end{aligned}
$$

Berdasarkan interpretasi kelompok responden, diperoleh nilai pelanggan Switcher merek mie Samyang adalah 2,47. Nilai yang dihasilkan ini termasuk dalam kategori jelek $(1,75-2,50)$. Salah satu faktor yang menyebabkan pembeli pindah adalah faktor harga produk dan pilihan mie yang mirip dengan samyang.

\section{Analisa Kepuasan Pembeli}

Kepuasan pembeli yang diteliti pada penelitian ini adalah apabila mereka menjawab pertanyaan terhadap harga dan kualitas yang ditawarkan oleh mie Samyang dengan jawaban "puas" maupun "sangat puas".

Tabel 7. Perhitungan Kepuasan Pembeli 
ISSN NO. (PRINT) 2598-0823, (ONLINE) 2598-2893

\begin{tabular}{lllllll}
\hline Jawaban & $\mathbf{f}$ & $\mathbf{X}$ & $\mathbf{f . X}$ & $\mathbf{X}^{2}$ & $\mathbf{f . X ^ { 2 }}$ & $\%$ \\
\hline Sangat Puas & 2 & 1 & 2 & 1 & 2 & 2.5 \\
\hline Tidak Puas & 2 & 2 & 4 & 4 & 8 & 2.5 \\
\hline Puas & 48 & 3 & 144 & 9 & 432 & 60 \\
\hline SSangat Puas & 28 & 4 & 112 & 16 & 448 & 35 \\
\hline U Total & 80 & & 262 & & 890 & 100 \\
\hline
\end{tabular}

ber: Pengolahan Data Primer, 2020

$$
\begin{array}{ll}
\text { Rata- } \text { Rata } & =\frac{\sum f \cdot X}{\sum f \text { Total }}=\frac{262}{80}=3,27 \\
\text { Satisfied Buyer } & =\frac{76}{80} \times 100=95 \%
\end{array}
$$

Hasil dari Tabel 7 di atas menyatakan bahwa mereka merasa puas terhadap produk Mie Samyang. Kepuasan pelanggan terhadap mie Samyang tersebut terlihat dari jawaban atas pertanyaan yang diberikan, bahwa mereka yang menjawab puas sebanyak 76 orang (95\%). Berdasarkan data pada interpretasi responden, nilai yang dihasilkan termasuk pada kelompok satisfied buyer sebesar 3,27. Nilai yang dihasilkan termasuk pada kelompok sangat baik $(3,25-4,00)$. Hal ini menunjukan bahwa konsumen mie Samyang yang puas/sangat puas saat mengkonsumsi produk tersebut.

\section{Kebiasaan Pembelian}

Hasil analisis terhadap kebiasaan pembelian yang dilakukan terhadap responden dengan menghitung jawaban "setuju" dan "sangat setuju" pada pertanyaan kuesioner kebiasaan pembelian.

Tabel 8. Perhitungan Kebiasaan Pembelian

\begin{tabular}{lllllll}
\hline Jawaban & $f$ & $X$ & $f . X$ & $X^{2}$ & $f . X^{2}$ & $\%$ \\
\hline Sangat Tidak Setuju & 3 & 1 & 3 & 1 & 3 & 3.75 \\
\hline Tidak Setuju & 14 & 2 & 28 & 4 & 56 & 17.5 \\
\hline Setuju & 46 & 3 & 138 & 9 & 414 & 57.5 \\
\hline Sangat Setuju & 17 & 4 & 68 & 16 & 272 & 21.25 \\
\hline Total & 80 & & 237 & & 745 & 100
\end{tabular}

Sumber : Sumber: Pengolahan Data Primer, 2020

$$
\begin{aligned}
& \text { Rata Rata }=\frac{\sum f . X}{\sum f \text { Total }}=\frac{237}{80}=2,96 \\
& \text { Habitual Buyer }=\frac{63}{80} \times 100=78,75 \%
\end{aligned}
$$


Hasil pada Tabel 8 di atas menyatakan, bahwa responden merasa betul-betul membeli karena kebiasaan melakukan pembelian pada merek Mie Samyang, Hal ini ditunjukkan dari jawaban mereka yang menjawab setuju dalam melakukan kebiasaan pembelian sebanyak 63 responden $(78,75 \%)$. Berdasarkan data pada tabel 8 di atas, dengan nilai interpretasi kelompok sebesar 2,96. Nilai tersebut termasuk dalam kategori baik $(2,50-3,35)$. Hasil ini menunjukan bahwa baik dalam kebiasaan mengkonsumsi produk mie Samyang.

\section{Menyukai Merek}

Komponen loyalitas merek yang lain adalah Menyukai Merek yang dibeli. Data yang diperoleh dari hasil pengolahan adalah sebagi berikut :

Tabel 9 Perhitungan Menyukai Merek

\begin{tabular}{lllllll}
\hline Jawaban & $\mathrm{f}$ & $\mathrm{X}$ & $\mathrm{f} . \mathrm{X}$ & $\mathrm{X}^{2}$ & $\mathrm{f} . \mathrm{X}^{2}$ & $\%$ \\
\hline $\begin{array}{l}\text { Sangat Tidak } \\
\text { Setuju }\end{array}$ & 3 & 1 & 3 & 1 & 3 & 3.75 \\
\hline Tidak Setuju & 14 & 2 & 28 & 4 & 56 & 17.5 \\
\hline Suka & 35 & 3 & 105 & 9 & 315 & 43.75 \\
\hline Sangat Suka & 28 & 4 & 112 & 16 & 448 & 35 \\
\hline Total & 80 & & 248 & & 822 & 100 \\
\hline
\end{tabular}

Sumber: Pengolahan Data Primer, 2020

$$
\begin{array}{ll}
\text { Rata }- \text { Rata } & =\frac{\sum f \cdot X}{\sum f \text { Total }}=\frac{238}{80}=3,1 \\
\text { Liking the brand } & =\frac{63}{80} x 100=78,75 \%
\end{array}
$$

Berdasarkan hasil dari Tabel 9 di atas, terlihat bahwa mereka merasa benar-benar menyukai merek Mie Samyang. Hasil yang diperoleh pada analisis menyukai merek samyang responden menjawab suka sebanyak 63 responden $(78,75 \%)$ dengan nilai ratarata interpretasi responden yang berada pada nilai 3,1. Nilai tersebut masuk dalam kategori baik $(2,50-3,25)$. Oleh karena itu, data ini menunjukan bahwa cukup banyak konsumen yang menyukai mie Samyang karena rasa koreanya.

\section{Komitmen Pembeli}

Komitmen pembeli dalam melakukan pembelian ini adalah keadaan yang diinginkan oleh setiap perusahaan. Hal ini disebabkan karena apabila konsumen sudah mencapai level atau tingkatan komit, maka konsumen untuk pindah ke produk lain sangat kecil. Mereka yang termasuk dalam pembeli yang mempunyai komitmen pembelian yang besar. Berikut adalah hasil dari kuesioner komitemen pembeli.

Tabel 10 Perhitungan Komitmen Pembeli

\begin{tabular}{lllllll}
\hline Jawaban & $\mathrm{f}$ & $\mathrm{X}$ & $\mathrm{f} . \mathrm{X}$ & $\mathbf{X}^{2}$ & f.X & $\%$ \\
\hline Tidak Pernah & 3 & 1 & 3 & 1 & 3 & 3.75 \\
\hline
\end{tabular}


ISSN NO. (PRINT) 2598-0823, (ONLINE) 2598-2893

\begin{tabular}{lllllll}
\hline Jarang & 24 & 2 & 48 & 4 & 96 & 30 \\
\hline Sering & 31 & 3 & 93 & 9 & 279 & 38.75 \\
\hline Selalu & 22 & 4 & 88 & 16 & 352 & 27.5 \\
\hline Total & 80 & & 232 & & 730 & 100 \\
\hline
\end{tabular}

Sumber: Pengolahan Data Primer, 2020

$$
\begin{array}{ll}
\text { Rata-rata } & =\frac{232}{80}=2,9 \\
\text { Committed Buyer } & =\frac{53}{80} \times 100=66,25 \%
\end{array}
$$

Hasil dari Tabel 10 di atas, terlihat responden yang termasuk pembeli yang memiliki komitmen sebanyak 53 orang $(66,25 \%)$. Responden tersebut loyal terhadap mie Samyang dan memiliki komitmen terhadap mie samyang. Nilai tingkatan commited buyer yang dihasilkan dari pengolahan data adalah sebesar 2,9. Nilai tersebut masuk dalam katageri Baik $(2,50-3,25)$. Hasil tersebut memperlihatkan bahwa sangat penting bagi perusahaan untuk selalu menjaga kualitas, harga maupun pelayanannya demi kemajuan perusahaan maupun keuntungan bagi perusahaan itu sendiri.

Berikut ini piramida yang dihasilkan dari perhitungan terhadap loyalitas Mie Samyang yang telah dilkukan :

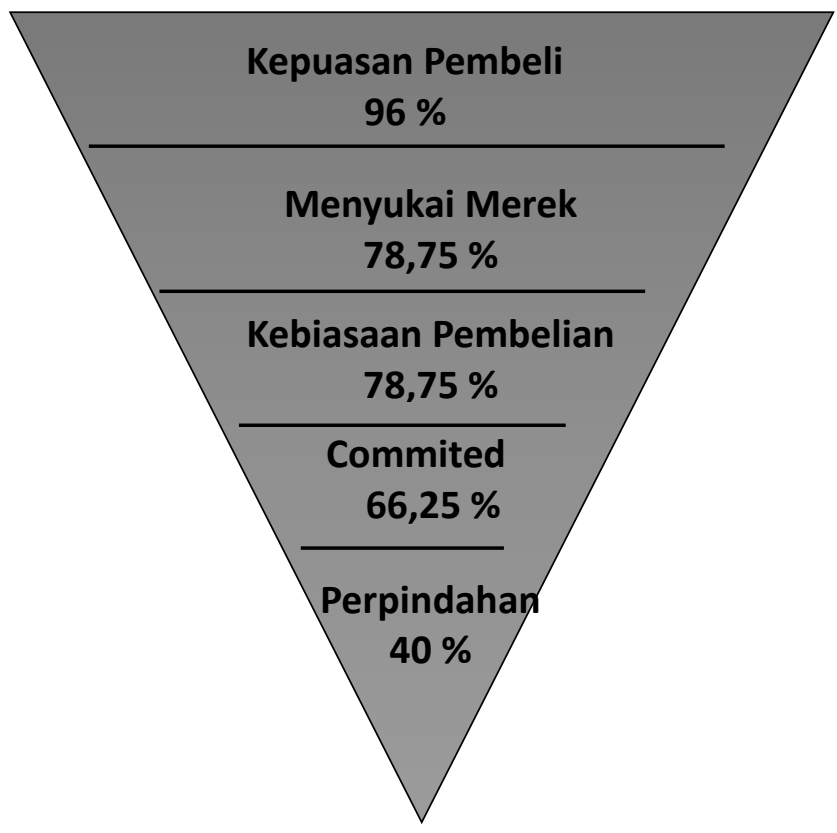

Sumber: Pengolahan Data Primer, 2020

Gambar 2. Piramida Brand Loyality Mie Samyang 
Dari gambar diatas terlihat bahwa merek mie Samyang sangat baik pada level konsumen yang puas (96\%). Informasi tersebut menunjukan bahwa konsumen merasa puas terkait dengan rasa, porsi yang disajikan maka dari itu minat para pembeli yang masuk pada kategori ini yang dapat sudah cukup baik dilihat dari kepuasan pembeli pada piramida di atas menunjukkan semakin keatas, piramida semakin melebar, tetapi pada tingkatan perpindahan piramida semakin mengkerucut (40\%). Hal ini merupakan pelanggan yang sama sekali tidak loyal atau mudah untuk berpindah ke merek lainnya.

\section{E. KESIMPULAN}

Responden perempuan lebih banyak yang mengenal dan pernah mengkonsumsi mie Samyang dan usia yang mengenal dan pernah mengkonsumsi mie Samyang adalah usia 17 hingga 21 tahun. Artinya, sebaiknya perusahaan melihat potensi pasar yang banyak tersebut agar selalu di kelola dengan baik, agar konsumen tetap loyal terhadap merek yang di keluarkan.

Responden dengan kategori konsumen yang melakukan perpindahan pembelian sebesar 2,47 . Hal ini menunjukkan bahwa nilai tersebut masuk dalam kategori jelek yang berarti konsumen memilih mie Samyang sering/selalu berpindah pindah, terutama karena faktor harga dan pilihan mie yang mirip dengan samyang. Pada analisis pembeli yang puas terhadap merek Mie Samyang, termasuk dalam kategori sangat baik, yaitu bernilai 3,27. Pada kebiasaan pembelian, yaitu konsumen yang merasa betul-betul membeli karena biasa pada merek Mie Samyang, adalah kategori baik, yaitu memiliki nilai 2,96. Pada kategori menyukai merek, Mie Samyang, masuk dalam kategori baik, yaitu mendapat nilai 3,1. Untuk kategori pembeli yang memiliki komitemen, terhadap mie Samyang adalah sebesar 2,9, nilai tersebut masuk dalam katageri baik. Oleh karena itu, perusahaan harus terus menjaga agar konsumen tetap loyal dengan selalu menjaga kualitas dan melakukan inovasi dan pengingatan periklanan.

\section{DAFTAR PUSTAKA}

Alma, B. (2018). Manajemen Pemasaran dan Pemasaran Jasa. Bandung: Alfabeta.

Hartanto, E. (2020). Penarikan Sampel Penelitian. academia.edu. https://www.academia.edu/12977584/Penarikan_Sampel_Penelitian

Husain, T., \& Sunardi, N. (2020). Firm's Value Prediction Based on Profitability Ratios and Dividend Policy. Finance \& Economics Review, 2(2), 13-26.

Kotler, P., \& Keller, K. L. (2018). Manajemen Pemasaran. (A. Maulana \& W. Hardani, Eds.) (13th ed.). Jakarta: Erlangga.

Kadim, A., Sunardi, N., \& Husain, T. (2020). The modeling firm's value based on financial ratios, intellectual capital and dividend policy. Accounting, 6(5), 859-870.

Nabilla, S. (2017). Pengaruh Citra Merek dan Minat Beli Terhadap Loyalitas Merek. Riset Sains Manajemen, 2(1), 31-38. https://doi.org/10.5281/zenodo.1039299

Nursaman, E., Sumarwan, U., \& Djohar, S. (2014). Ekuitas Merek Jasa Gerai Buah-buahan Berdasarkan Persepsi Konsumen. Manajemen Dan Agribisnis, 11(2), 89-99. https://journal.ipb.ac.id/index.php/jmagr/article/view/9046/7111

Putri, S. N., Kusumaningrum, \& Arijanto, S. (2014). Pengukuran BrandEquityJasa Pengiriman Barang Di PT. Pos Indonesia (Persero). Online Institut Teknologi Nasional, 02(03), 2338-5081.

Lesmana, R., \& Nabila, N. I. (2020, June). Analisis Loyalitas Wisatawan Lokal Melalui 
Kepuasan Wisatawan Studi Kasus Pada Objek Wisata Kepulauan Seribu Jakarta. In Proceedings (Vol. 1, No. 1).

Lesmana, R., Widodo, A. S., \& Sunardi, N. (2020). The Formation of Customer Loyalty From Brand Awareness and Perceived Quality through Brand Equity of Xiaomi Smartphone Users in South Tangerang. Jurnal Pemasaran Kompetitif, 4(1), 1-12.

Samsudin, S. (2019). Analisis Loyalitas Pelanggan Di Pt Nutrifood, Kotamadya Bogor. Transparansi Jurnal IImiah IImu Administrasi, 1(2), 179-193. https://doi.org/10.31334/trans.v1i2.302

Susanto, K., Ferdinand, H., Gunawan, R., \& Sihombing, S. O. (2018). Loyalitas Merek Pada Jasa Penerbangan: Suatu Studi Empiris. Esensi: Jurnal Bisnis Dan Manajemen, 8(1), 1-8. https://doi.org/10.15408/ess.v8i1.5553

Sutarman, A., \& Lesmana, R. (2019, January). Analisis Keputusan Pembelian Konsumen dari Sisi Normtif dan Informatif Pada Supermarket Giant Pamulang, Tangerang Selatan. In PROCEEDINGS (Vol. 1, No. 1).

Tjiptono, F. (2015). Strategi Pemasaran (4th ed.). Yogyakarta: ANDI.

Widadi, R. H. S., \& Wadji, F. (2015). Faktor-Faktor yang Berpengaruh pada Loyalitas Pelanggan Klinik Saraf Rumah Sakit Jiwa Daerah Dr. R.M. Soedjarwadi. Jurnal Manajemen DayaSaing, 17(1), 28-37. Retrieved from http://journals.ums.ac.id/index.php/dayasaing/article/view/2270/1540

Widoyoko, S. E. P. (2017). Teknik Penyusun Instrumen Penelitian. Yogyakarta: Pustaka Pelajar. 